\title{
ПСИХОЛОГИЧЕСКИЕ ИССЛЕДОВАНИЯ
}

\section{ANXIETY AS A PREVAILING FACTOR OF PERFORMANCE OF UNIVERSITY MATHEMATICS STUDENTS DURING THE COVID-19 PANDEMIC}

\author{
D. Mendoza \\ Universidad UTE, Quito, Ecuador; \\ Universidad Nacional de Educación (UNAE), Azogues, Ecuador. \\ E-mail: derling.mendoza@ute.edu.ec
}

M. Cejas

Universidad Nacional de Chimborazo (UNACH), Riobamba, Ecuador; Universidad de las Fuerzas Armadas (ESPE), Latacunga, Ecuador. E-mail:magda.cejas@unach.edu.ec

G. Rivas

Instituto Tecnológico Superior Quito Metropolitano (ITSQMET), Quito, Ecuador; Libertador Experimental Pedagogical University (UPEL), Barquisimeto, Venezuela. E-mail:gabrielarivasu@gmail.com

C. Varguillas

Universidad Nacional de Chimborazo (UNACH), Riobamba, Ecuador.

E-mail: cvarguillas@unach.edu.ec

\begin{abstract}
Introduction. Anxiety is characterised by feelings of tension, apprehension or fear. It arises from concern about student performance at university, with an emphasis on exact science subjects. It is not only students, who suffer from mathematical anxiety. However, anxiety is a predominant factor in student performance at all levels.

Aim. The aim of the research was to describe the levels of anxiety also known as distress manifested by university mathematics students studying at the Universidad Nacional de Chimborazo (UNACH) during the 2020-1 academic semester.

Methodology and research methods. The current study was carried out applying the quantitative paradigm. It is of a descriptive exploratory design. The total sample consisted of 120 students, who are preparing at their university level, and, who are studying the subject of mathematics at different levels and careers at UNACH. The selection of the sample was of an intentional non-probabilistic type and having as inclusion criteria not having been diagnosed with an anxiety disorder. As a measurement instrument, the Short Inventory of Anxiety Situ-
\end{abstract}


ations and Responses-ISRA-B was applied. ISRA-B was sent to students by email to facilitate data collection.

Results. The results were analysed by means of the two-factor ANOVA calculation (mathematics and understanding). The results showed that there are statistically significant differences in the understanding of the contents presented by the teachers in a virtual way. During the COVID-19 pandemic the levels of mathematical anxiety increased. Teaching mathematics at university in online format requires the assessment of digital connection and time limited submission of assignments. These factors limit understanding and generate mathematical anxiety.

Scientific novelty. In face-to-face education, mathematical anxiety is common. But because of the pandemic, mathematics education has had to migrate to the virtual environment. The present research reflects the impact of anxiety not only on mathematics education and academic performance but also on the emotions of students. The data collection instruments ISRA-B-C, ISRA-B-F and ISRA-B-M are innovative and adaptable to all levels of education.

Practical significance. The importance of mathematics and the overestimation of its difficulties cause great concern for the learning of this subject in studies at a higher university level. The current studies of virtual mathematical anxiety are important because they allow the detection and analysis of possible educational failures in online learning. The failures of online education have a direct impact not only on performance and learning, but on an emotional state of students.

Keywords: university education, COVID-19, mathematics, anxiety, quantitative research, Ecuador.

For citation: Mendoza D., Cejas M., Rivas G., Varguillas C. Anxiety as a prevailing factor of performance of university mathematics students during the COVID-19 pandemic. The Education and Science Journal. 2021; 23 (2): 94-113. DOI: 10.17853/1994-5639-20212-94-113

\title{
ТРЕВОГА КАК ПРЕОБЛАДАЮЩИЙ ФАКТОР УСПЕВАЕМОСТИ СТУДЕНТОВ МАТЕМАТИЧЕСКИХ НАПРАВЛЕНИЙ УНИВЕРСИТЕТА ВО ВРЕМЯ ПАНДЕМИИ COVID-19
}

\author{
Д. Мендоса \\ Центральный университет (UTE), Кито, Эквадор; \\ Наииональный университет образования (UNAE), Асогес, Эквадор.
} E-mail: derling.mendoza@ute.edu.ec

M. Cexac

Наииональный университет Чимборасо (UNACH); Риобамба, Эквадор; Университет вооруженных сил (ESPE), Аатакунга, Эквадор.

E-mail: magda.cejas@unach.edu.ec 


\section{Г. Ривас}

Городской технологический институт Кито (ITSQMET), Кито, Эквадор; Экспериментальный университет образования Libertador (UPEL), Баркисимето, Венесуэла. E-mail: gabrielarivasu@gmail.com

К. Варгуиллас

Национальный университет Чимборасо (UNACH); Риобамба, Эквадор.

E-mail: cvarguillas@unach.edu.ec

Аннотация. Введение. Тревога характеризуется чувством напряжения, опасения или страха. Она возникает из-за беспокойства студентов (особенно обучающихся точным наукам) по поводу своей успеваемости в университете, однако является доминирующим фактором успеваемости учащихся на всех уровнях.

Цель исследования - описать уровни тревоги, также известные как дистресс (напряжение), которые испытывали студенты математических факультетов Национального университета Чимборасо (UNACH) в течение первого академического семестра 2020 года.

Методология и методы. Работа проведена с использованием количественной парадигмы и носит исследовательский описательный характер. Респондентами выступили 120 студентов, изучающих математику на разных уровнях и специальностях в Национальном университете Чимборасо (UNACH). Выборка была преднамеренной детерминированной. Критерий для вкАючения - отсутствие тревожного расстройства у учащихся. В качестве инструмента измерения использовался "Инвентаризационный перечень тревожных ситуаций и ответов" (ISRA-B), который рассылался студентам по эмектронной почте для облегчения сбора данных.

Результаты. Результаты были проанализированы путем расчета двухфакторного дисперсионного анализа ANOVA (изучение математики и понимание содержания). Результаты исследования показали, что существуют статистически значимые размичия в понимании содержания, представленного преподавателями в виртуальном виде. Уровни "математической тревоги" повысились во время пандемии COVID-19. Преподавание математики в университете в онлайн-формате требует оценки интернет-соединения и сдачи заданий в сжатые сроки. Эти факторы ограничивают понимание и порождают "математическую тревогу".

Научная новизна. При очном обучении часто встречается "математическая тревога». Из-за пандемии математическое образование вынуждено было мигрировать в виртуальную среду. Данное исследование отражает влияние тревоги не только на математическое образование и успеваемость, но и на эмоции учащихся. Средства сбора данных ISRA-B-C, ISRA-B-F и ISRA-B-M явАяются инновационными и адаптируемыми для всех уровней образования.

Практическая значимость. Важность математики и завышение ее сложности вызывают большую озабоченность при изучении этого предмета в высших учебных заведениях. Современные исследования виртуальной "математической тревоги" важны, так как позволяют обнаружить и проанализировать возможные недостатки в дистанционном образовании, которые отражаются не только на успеваемости и обучении, но и на эмоциональном состоянии учащихся.

Образование и наука. Том 23, № 2. 2021 / The Education and Science Journal. Vol. 23, № 2. 2021 
Ключевые слова: университетское образование, COVID-19, математика, тревога, количественные исследования, Эквадор.

для иитирования: Мендоса Д., Сехас М., Ривас Г., Варгуимлас К. Тревога как преобладающий фактор успеваемости студентов математических направцений университета во время пандемии COVID-19. Образование и наука. 2021. Т. 23, № 2. С. 94-113. DOI: $10.17853 / 1994-5639-2021-2-94-113$

\section{Introduction}

The fact of living implies an interdependence with the environment in which life develops. It is lived as a process of development of powers in a specific environment that qualifies, conditions, modifies the original being. These circumstances make it necessary to maintain an adaptive tension that adapts' the actions to the environment in which they develop, based on the individual's own characteristics. Precisely, this nuclear presence within human reactions has caused anxiety to be a source of interest for many researchers belonging to the most diverse schools: and, consequently, that their concept lacks absolute precision as it has been approached from such different perspectives [1]. Therefore, it is necessary to clarify its true meaning and correspondence in university mathematics.

The continuous attempt to understand the nature and role that anxiety plays in daily life is demonstrated by the intensive and extensive research that has existed in this area for many years. However, the difficulties encountered along this path are many, beginning with the conceptual ambiguity of the anxiety construct and ending with the methodological problems present in the attempt to deal with it in an operative way. In a simplistic way, anxiety can be considered as a state of restlessness of the individual.

At the university level, learning mathematics has been one of the main columns on which the educational system in Ecuador rests, which can be easily verified through academic plans and curricula in all engineering majors. For Lara [2] in engineering schools it is considered legendary math difficulty. This difficulty has been incorporated into the Ecuadorian culture and idiosyncrasy from an early age. Through various studies, interviews, questionnaires among others, to students, it has been defined that mathematical anxiety originates in homes [3].

These beliefs are based on the Pygmalion effect of Santibáñez [4] this effect is generated in a coherent relationship between the negative attitude of students towards mathematics and the result they obtain. That is, a series of negative comments about mathematics [5]. Negative comments can result in this fear of failure becoming a reality, resulting in a vicious circle, as students fear mathematics, so they resist it and fail. That is, they fail because they fear and resist it. 
Since March 14, 2020, in the Republic of Ecuador a national quarantine decree was issued, as a preventive measure to prevent the spread of the COVID-19 virus. All universities went from face-to-face mode to online mode. The authors of the current research carry out a study that aims to describe the anxiety levels manifested by mathematics students of the Engineering Faculty of the National University of Chimborazo UNACH during the academic semester 20201. To develop the study below, the following support or theoretical contributions from different authors related to the research topic are presented.

\section{Literature Review}

\section{Anxiety as an emotional state in the student}

Anxiety is an emotional state that appears in normal life circumstances and is inseparable for human survival [6]. Certain circumstances can be evaluated by the person in an uncertain way, reaching the possibility of predicting negative or threatening consequences for personal interests. From then on, a process of preparation for action starts from the activation of the body's own cognitive, physiological, behavioural systems [7]. This state of activation tries to optimise the person's response to the situation.

However, the emotional response of anxiety is not always adaptive because on many occasions situations that are evaluated as possible threats in a wrong way tend to occur. In some individuals the activation of the anxiety system occurs without having reasons to do so. In other cases, the perception of threat occurs at maximised levels, causing very intense emotional activations that usually produce deficiencies in performance, mental health problems (for example, anxiety disorders) and physical (for example, psychophysiological disorders due to excess activation) [7]. Likewise, the chronification of anxiety states can initiate long-lasting and disabling psychopathological disorders [8].

\subsection{Anxiety is a key factor in student performance}

Anxiety can be summarised as an emotion close to fear or as a subtype of fear. One of the criteria to differentiate 'anxiety' and 'fear' is proportionality. According to this estimation key, fear would be a more proportionate reaction to real danger than anxiety. Be it as indicated by Graham [9] that 'anxiety' and 'fear' are synonymous in most cases, although in the psychological literature they find a preference for one term or another based on the "real dangerousness of the stimulus". This weighing, on the other hand, is highly complex, since personal reaction depends more on subjective perception than on objective threat.

The word 'fear' should be reserved to designate the emotional reaction of fear to a concrete, real and precise danger [10]. The term 'anxiety', on the other hand, refers to fear that is experienced in an indeterminate way, without the presence of an object. Fear is the trimeric state of the object and anxiety of the subject. 


\subsection{Anxiety and distress}

There are authors who differentiate between anguish and anxiety. Broadly speaking, anxiety would be the emotional state characterised by awe, inhibition, the predominance of somatic and visceral symptoms, while anxiety is distinguished by startle, restlessness, and greater psychic richness. For Islam [11] nowadays when speaking of anxiety, reference is made to both psychological and cognitive symptoms and physical and behavioural symptoms, which are attributed with preference to anguish. Today, rather, both concepts are separated according to psychological guidelines. The term 'anxiety' is used above all by scientific psychology and the term 'anguish' by humanistic psychology and psychoanalysis.

\subsection{Anxiety and stress}

There are many common elements between anxiety and stress, which makes them especially difficult to differentiate. The term 'anxiety' refers to the inner experience of uneasiness and uneasiness devoid of object. In anxiety fear is diffuse, vague. The term 'stress', on the other hand, can be reserved to designate the emotional overload that is produced by a prolonged external force that puts the subject on the brink of exhaustion [12].

Arousal is the body's reaction to any form of intense stimulation. It is the general level of activation, common to the different emotions. Gould and Krane [13] define the arousal as a general physiological and psychological activation of the organism, variable along a continuum that goes from deep sleep to intense excitement. Anxiety, on the other hand, could be defined as the arousal caused specifically by the perception of danger. The proximity of anxiety to other concepts, especially stress, complicates our claim to exclusively calibrate its presence in university students.

Nor can we ignore the comorbidity of anxiety with other disorders, such as depression. Serrano, Rojas and Ruggero [14] state that anxiety and depression frequently overlap, in such a way that in practice it is not unusual to observe depressions with a great load of anxiety or anxiety pictures clouded with depressive symptoms. In any case, the conditions to indicate that the main anxiogenic sources in students are the competitive academic environment, the technicalities in engineering, the overload of tasks, the lack of solid relationships with colleagues or teachers, the horizon of unemployment.

\subsection{College anxiety}

Anxiety, as with depression, is one of the psychological disorders most registered in health centres in the general population and with a greater presence in the university environment [15]. In the world of work, especially if there is exposure to risks of various kinds, including psychosocial risks, concern about problems of anxiety, stress and depression has spread, frequently resulting in 
sick leave [16]. These disorders are not exclusive to workers. New demands, competitiveness, rapid changes and, of course, the economic crisis, especially in Ecuador, threaten the mental health of many university students. For example, in the unfortunate situation of unemployment, deeply anxious and dipsogenic, and which begins to be experienced before obtaining a university degree and looking for work. In a significant number of students, especially in the last years, there is a lot of fear of unemployment, which is also accompanied by tensions and conflicts, an expression of psychological discomfort.

\subsection{Math anxiety}

According to Palacios et al. [17] the terminology mathematical anxiety is used, sometimes, ambiguously, almost always with different meanings in each case. Based on this, according to Hembree [18], math anxiety is rooted in a fear of meeting mathematics, which includes classes, homework, and tests. This conception is also based on the physiological studies carried out by Escalera et al. [19], who found important relationships between the manifestations associated with fear and those observed from the perspective of mathematics courses and exams.

Smith [20] has defined anxiety towards mathematics as the restlessness that students experience when they perform mathematical operations, as well as the anguish of failing an exam in this discipline. Seng [21] describes mathematical anxiety as a feeling of nervousness that prevents the use of numbers, being able to solve mathematical operations in daily life, as well as in academic spaces. In this same sense, Devine et al. [22] specify Mathematical Anxiety (MA) as a state of restlessness caused by carrying out mathematical tasks and which is manifested through feelings of apprehension, aversion, tension , worry, frustration and fear, in addition to pointing out that environmental factors (negative experiences in class), intellectual (degree of thinking), and personality (self-esteem, learning style, attitude and confidence) influence to generate this feeling in students and consequently they cannot develop their full capacity.

\section{Methodology}

The study is in the quantitative paradigm of descriptive exploratory design. According to Hernández, Fernández and Baptista [23] the quantitative methodology is based on three axes, first in obtaining or collecting quantitative data, which are subsequently analysed in a descriptive way, secondly a support or analytical contribution is developed through the search for information that complements the quantitative phase, finally its third axis consists of contrasting the results through the integration, interpretation and preparation of a final report or conclusion. 


\section{Population and sample}

The population defined by Erba et al. [24] and Nguyen et al. [25] as a complete set of elements (people or objects) that have some common characteristic defined by the sampling criteria established by the researcher. For the purposes of the study, the population is made up of 2,900 students attached to the UNACH of Ecuador. The sample represents the selected elements (people or objects) chosen to participate in a study; people are called subjects or participants [26]. The total sample consisted of $N=120$ students studying mathematics, which are at different levels and careers of the Engineering Faculty. The selection of the sample was of an intentional non-probabilistic type and having as inclusion criteria not having been diagnosed with an anxiety disorder.

\section{Data collection instrument}

As a measurement instrument, the adaptation of the Inventory of Anxiety Situations and Responses-ISRA-B was applied. The ISRA-B was adapted to the activities and situations of mathematics. The questionnaire was sent to the students by email to facilitate data collection. The results were analysed using a two-factor ANOVA (mathematics and comprehension). The ISRA-B was designed by Tobal and Cano [27]. This shortened version of the instrument was developed from items derived from the original ISRA [28]. The 24 items evaluate anxiety responses at the cognitive level (7 items, "I worry too much", e.g.), physiological (10 items, "My hands or legs are shaking", for example) and motor (7 items, "I move around and do things without a specific purpose", e.g.). Students must respond using a 5-position Likert scale.

The first option "Almost Never" with a value of "O", then the option "Few Times" with a value of "1". The option "Sometimes" with a value of " 2 ". Then the option "Many times" with a value of " 3 " points, finally the option "Almost always" with a value of " 4 " points. These questions inquire about the existence of stressful events in recent months from March to July 2020, (during the COVID-19 quarantine), the level of perceived demand and the intensity of perceived stress (Table 1).

Table 1

Instrument for measuring anxiety at a cognitive level applied to students studying mathematics in the Engineering Faculty of UNACH during the period March - July 2020

\begin{tabular}{|c|c|c|c|}
\hline \multicolumn{3}{|c|}{ ISRA-B } & $\mathrm{C}$ \\
\hline \multicolumn{3}{|c|}{$\begin{array}{l}\text { Universidad Nacional } \\
\text { de Chimborazo UNACH }\end{array}$} & Engineering Faculty \\
\hline \multicolumn{2}{|c|}{$\begin{array}{l}\text { Last names and } \\
\text { name: }\end{array}$} & & \\
\hline Age: & Gender: & Date: & Course: \\
\hline
\end{tabular}




\begin{tabular}{|c|c|c|c|c|c|c|}
\hline & $\begin{array}{l}\text { n the next page you will } \\
\text { hich you could find you } \\
\text { ve to those situations or } \\
\text { e numbered on the left } \\
\text { west frequency and } 4 \text { th } \\
\text { action level you are con }\end{array}$ & $\begin{array}{l}1 \text { find a series } \\
\text { rself and oth } \\
r \text { reactions th } \\
\text { side of the } p \\
\text { te highest fre } \\
\text { isidering. }\end{array}$ & $\begin{array}{l}\text { s of sentence } \\
\text { hers that refe } \\
\text { hat they wou } \\
\text { age. Your ta } \\
\text { equency), ea }\end{array}$ & $\begin{array}{l}\text { s that prese } \\
\text { r to respons } \\
\text { ld produce. } \\
\text { sh is to rate } \\
\text { ch of the foll }\end{array}$ & $\begin{array}{l}\text { nt situatio } \\
\text { es that you } \\
\text { The } 10 \text { sit } \\
\text { from } 0 \text { to } \\
\text { owing situ }\end{array}$ & $\begin{array}{l}\text { s in } \\
\text { could } \\
\text { lations } \\
\text { ( } 0 \text { the } \\
\text { tions or }\end{array}$ \\
\hline & Situations & & & Situations & & \\
\hline 密 & & $\begin{array}{c}\text { 1. I get } \\
\text { confused } \\
\text { and do not } \\
\text { know what } \\
\text { to do }\end{array}$ & \begin{tabular}{|c|}
$2 . \mathrm{I}$ \\
have the \\
impression \\
that I am \\
useless
\end{tabular} & \begin{tabular}{|l} 
3. I cannot \\
concen- \\
trate on \\
the lesson
\end{tabular} & $\begin{array}{l}\text { 4. I have } \\
\text { difficulty } \\
\text { sleeping }\end{array}$ & $\begin{array}{c}5 . \mathrm{I} \\
\text { lose my } \\
\text { appetite }\end{array}$ \\
\hline 1 & $\begin{array}{l}\text { If a math problem } \\
\text { worries me too much }\end{array}$ & & & & & \\
\hline 2 & $\begin{array}{l}\text { When I lose my math } \\
\text { homework }\end{array}$ & & & & & \\
\hline 3 & $\begin{array}{l}\text { If my computer or } \\
\text { mobile phone is } \\
\text { damaged }\end{array}$ & & & & & \\
\hline 4 & $\begin{array}{l}\text { When I do not have } \\
\text { internet and I cannot } \\
\text { enter the virtual } \\
\text { class }\end{array}$ & & & & & \\
\hline 5 & $\begin{array}{l}\text { Not understanding } \\
\text { the math lesson }\end{array}$ & & & & & \\
\hline 6 & $\begin{array}{l}\text { When I finish my } \\
\text { homework and am } \\
\text { free from activities }\end{array}$ & & & & & \\
\hline 7 & $\begin{array}{l}\text { No matter how much } \\
\text { I study, math is } \\
\text { always difficult for } \\
\text { me }\end{array}$ & & & & & \\
\hline
\end{tabular}

In Table 2, the questions applied in the ISRA-B F questionnaire are presented. These questions were related to physiological responses. The questionnaire has 10 situations that are presented during online academic activities. For example, in the first situation: "I tend to abandon a math problem that seems too difficult or too long". In this way students can express their body perceptions, with 0 being the lowest frequency and 4 the highest. 
Table 2

An anxiety measurement instrument at the physiological level applied to students who study mathematics at the Engineering Faculty of UNACH during the period March - July 2020

\begin{tabular}{|c|c|c|c|c|c|c|c|c|c|c|c|c|c|}
\hline \multirow{2}{*}{\multicolumn{4}{|c|}{$\begin{array}{c}\text { ISRA-B } \\
\text { Universidad Nacional de Chimborazo } \\
\text { UNACH }\end{array}$}} & \multicolumn{10}{|c|}{$\mathrm{F}$} \\
\hline & & & & \multicolumn{10}{|c|}{ Engineering Faculty } \\
\hline \multicolumn{14}{|c|}{ Last names and name: } \\
\hline \multicolumn{2}{|c|}{ Age: } & Gender: & Age: & \multicolumn{10}{|c|}{ Course: } \\
\hline \multicolumn{14}{|c|}{$\begin{array}{l}\text { On the next page you will find a series of sentences that present situations in } \\
\text { which you could find yourself and others that refer to responses that you could } \\
\text { give to those situations or reactions that they would produce. } \\
\text { The } 10 \text { situations are numbered on the left side of the page. } \\
\text { Your task is to rate from } 0 \text { to } 4 \text { ( } 0 \text { the lowest frequency and } 4 \text { the highest } \\
\text { frequency), each of the following situations or reaction level you are considering. } \\
\text { Situation: } \\
\text { 1. I feel discomfort in my stomach / 2. My hands or other part of my body sweat, } \\
\text { until I feel cold / 3. My hands or legs are shaking / } 4 \text {. My head hurts / 5. My } \\
\text { body is in tension / } 6 \text {. I have very frequent heart palpitations / 7. I am short of } \\
\text { breath and my breathing is sharp/ } 8 \text {. I feel nauseous or dizzy / 9. My mouth is } \\
\text { dry; I have difficulty swallowing / } 10 \text {. I have chills }\end{array}$} \\
\hline \multirow[b]{2}{*}{ No. } & \multirow{2}{*}{\multicolumn{3}{|c|}{ Situations }} & \multicolumn{10}{|c|}{ Situations } \\
\hline & & & & 1. & 2. & 3. & 4. & 5. & 6. & 7. & 8. & 9. & 10. \\
\hline 1 & \multicolumn{3}{|c|}{$\begin{array}{l}\text { I tend to abandon a math problem } \\
\text { that seems too difficult or too long }\end{array}$} & & & & & & & & & & \\
\hline 2 & \multicolumn{3}{|c|}{$\begin{array}{l}\text { When deciding or solving a difficult } \\
\text { algebraic problem }\end{array}$} & & & & & & & & & & \\
\hline 3 & \multicolumn{3}{|c|}{$\begin{array}{l}\text { When someone bothers me or when I } \\
\text { argue }\end{array}$} & & & & & & & & & & \\
\hline 4 & \multicolumn{3}{|c|}{$\begin{array}{l}\text { When I am observed, when I receive } \\
\text { criticism, or whenever I can be } \\
\text { negatively evaluated }\end{array}$} & & & & & & & & & & \\
\hline 5 & \multicolumn{3}{|c|}{ If I must speak in public } & & & & & & & & & & \\
\hline 6 & \multicolumn{3}{|c|}{$\begin{array}{l}\text { After having made a mistake and was } \\
\text { already sent to the teacher's platform }\end{array}$} & & & & & & & & & & \\
\hline 7 & \multicolumn{3}{|c|}{$\begin{array}{l}\text { When I think about my future as an } \\
\text { engineer or future difficulties and } \\
\text { problems }\end{array}$} & & & & & & & & & & \\
\hline 8 & \multicolumn{3}{|c|}{$\begin{array}{l}\text { When being in my house closed or } \\
\text { closed spaces }\end{array}$} & & & & & & & & & & \\
\hline 9 & \multicolumn{3}{|c|}{$\begin{array}{l}\text { When watching violent scenes on TV } \\
\text { / PC / mobile }\end{array}$} & & & & & & & & & & \\
\hline 10 & \multicolumn{3}{|c|}{ At bedtime } & & & & & & & & & & \\
\hline
\end{tabular}


Table 3 presents the applied questions of ISRA-B M. Seven situations frequently encountered by university students were drafted. These questions aim to analyse the attitudes or behaviours of students during the COVID-19 pandemic. Anxiety body movement can be detected by the frequency of drinking, eating, smoking, stuttering, lack of verbal expression, avoidance of situations, among others. These symptoms of anxiety can be perceived by being in a sedentary and quarantined state for a long time.

Table 3

Anxiety measurement instrument at the motor level applied to students studying mathematics in the Engineering Faculty of UNACH during the period March - July 2020

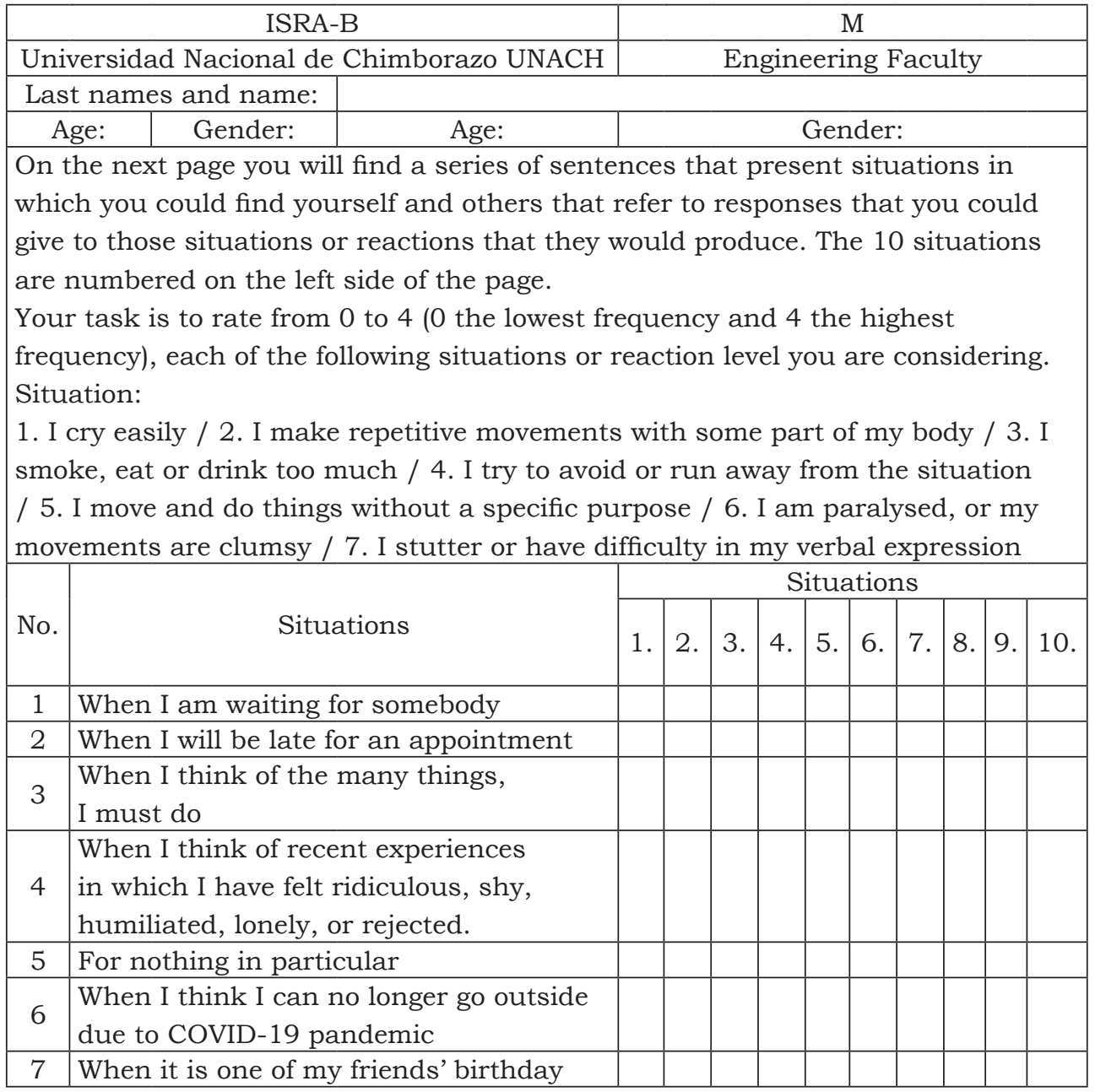




\section{Reliability of the instruments}

In samples of the student population, a pilot test was applied, directed to 5 students to measure the level of reliability of the instruments. Cronbach's Alpha statistical coefficient was used. The first ISRA-B-C instrument resulted in 0.893, the ISRA-B-F instrument returned 0.931, and the ISRA-B-M instrument returned 0.872 . The results show that the instruments are reliable and safe in their application, having a value that ranges between 0.700 and 0.999 according to Mendoza et al. [29]. Once the test was selected, it was applied collectively in the first quarter of the 2020-1 academic year. The participants, after receiving the instructions, voluntarily agreed to fill out the questionnaire, anonymously.

\section{Analysis of the results}

The data analysis includes a descriptive analysis on the anxiety variable measured with the ISRA, such as the mean and standard deviation. Likewise, to evaluate the possible differences in anxiety in different groups (based on mathematics and comprehension), a two-factor ANOVA was applied, the independent variables being mathematics and comprehension. The data processing was carried out through the statistical package Statistical Package for the Social Sciences (SPSS) version 25.

\section{Results and Discussion}

Table 4 shows the descriptive analyses, means and standard deviations separated by mathematics and comprehension for the response systems (cognitive, physiological, and motor) and general level of anxiety (A).

Table 4

Statistical results of the means and standard deviations of the mathematical factors and comprehension in the three response systems and the general level of anxiety $(\mathrm{N}=120)$

\begin{tabular}{|c|c|c|c|}
\hline \multirow{2}{*}{ Answer system } & & \multicolumn{2}{|c|}{ Factors } \\
\cline { 2 - 4 } & & Mathematics & Comprehension \\
\hline \multirow{2}{*}{ Cognitive } & $\overline{\mathrm{x}}$ & 50.78 & 67.78 \\
\cline { 2 - 4 } & $\mathrm{DT}$ & 20.89 & 28.89 \\
\hline \multirow{2}{*}{ Physiologic } & $\overline{\mathrm{x}}$ & 34.26 & 41.85 \\
\cline { 2 - 4 } & $\mathrm{DT}$ & 21.03 & 21.40 \\
\hline \multirow{2}{*}{ Motor } & $\overline{\mathrm{x}}$ & 36.89 & 39.45 \\
\cline { 2 - 4 } & $\mathrm{DT}$ & 24.70 & 21.48 \\
\hline $\begin{array}{c}\text { General anxiety } \\
\text { level }\end{array}$ & $\overline{\mathrm{x}}$ & 110.89 & 92.78 \\
\cline { 2 - 4 } & $\mathrm{DT}$ & 59.87 & 48.45 \\
\hline
\end{tabular}


Table 5 shows the means and standard deviations for the specific anxietygenerating traits or situations (AI: evaluation anxiety, AII: phobic anxiety, AIII: mathematical anxiety and AIV: virtual anxiety).

Table 5

Means and standard deviations of the different factors of the mathematical and comprehension sample in the four situational areas or specific traits $(N=120)$

\begin{tabular}{|c|c|c|c|}
\hline \multirow{2}{*}{$\begin{array}{c}\text { Situational areas } \\
\text { or specific traits }\end{array}$} & & \multicolumn{2}{|c|}{ Factors } \\
\cline { 2 - 4 } & & Mathematics & Comprehension \\
\cline { 2 - 4 } AI & $\overline{\mathrm{X}}$ & 60.47 & 75.56 \\
\hline \multirow{2}{*}{ AII } & $\overline{\mathrm{DT}}$ & 34.58 & 30.48 \\
\cline { 2 - 4 } & $\overline{\mathrm{x}}$ & 34.89 & 28.12 \\
\hline \multirow{2}{*}{ AIII } & $\mathrm{DT}$ & 24.37 & 81.48 \\
\cline { 2 - 4 } & $\overline{\mathrm{x}}$ & 79.42 & 34.07 \\
\hline \multirow{2}{*}{ AIV } & $\mathrm{DT}$ & 40.04 & 90.10 \\
\cline { 2 - 4 } & $\overline{\mathrm{x}}$ & 87.14 & 51.47 \\
\hline
\end{tabular}

\section{Relationship between mathematical factors and understanding in the response system and situational factors}

The analysis of variance on the three response systems Cognitive (C), Physiological (F) and Motor (M) and at the level of the general anxiety trait (A) presented significant differences in terms of understanding with the following values: in the system cognitive (F $3.614=13.43$, p < 0.001$)$, in the physiological system $(\mathrm{F} 3.742=6.81 \mathrm{p}=0.014)$ and for the total or general trait $(\mathrm{F} 3.642=7.41$, $\mathrm{p}=0.029$ ). However, there was no difference in anxiety between mathematics and understanding in the motor system. On the other hand, no statistically significant differences were revealed between both factors (Table 6).

Table 6

Analysis of variance according to comprehension and mathematics in the three response systems and the general level of anxiety

\begin{tabular}{|c|c|c|c|c|c|}
\hline $\begin{array}{c}\text { Dependent } \\
\text { variables }\end{array}$ & Variation Sources & $\begin{array}{c}\text { Sum of } \\
\text { Squares }\end{array}$ & $\begin{array}{c}\text { Quadratic } \\
\text { Media }\end{array}$ & $F$ & $p$ \\
\hline \multirow{2}{*}{ Cognitive } & Mathematics & 11.01 & 11.01 & 0.1 & 0.902 \\
\cline { 2 - 6 } Physiologic & Comprehension & 10548.47 & 10548.47 & 13.04 & 0.001 \\
\hline \multirow{2}{*}{ Motor } & Mathematics & 3.30 & 3.30 & 0.1 & 0.931 \\
\cline { 2 - 6 } & Comprehension & 3197.14 & 3197.14 & 6.17 & 0.123 \\
\cline { 2 - 6 } & Mathematics & 3.40 & 3.40 & 0.01 & 0.924 \\
\hline \multirow{2}{*}{$\begin{array}{c}\text { General } \\
\text { anxiety level }\end{array}$} & Mathematics & 308.48 & 308.48 & 0.67 & 0.117 \\
\cline { 2 - 6 } & Comprehension & 39147.61 & 39147.61 & 8.15 & 0.028 \\
\hline
\end{tabular}


The analysis of variance carried out in the four specific traits or areas that generate anxiety (AI, AII, AIII and AIV), showed statistical differences in terms of mathematics, in evaluation situations $(\mathrm{F} \mathrm{3.429}=10.96, \mathrm{p}=0.001)$ and situations of everyday life ( F $3.453=10.97, \mathrm{p}=.01)$, with no differences in interpersonal or phobic situations. Nor were there significant differences based on mathematics (Table 7).

Table 7

Analysis of variance according to understanding and mathematics in the four situational areas or specific traits

\begin{tabular}{|c|c|c|c|c|c|}
\hline $\begin{array}{c}\text { Dependent } \\
\text { variables }\end{array}$ & Variation Sources & $\begin{array}{c}\text { Sum of } \\
\text { squares }\end{array}$ & $\begin{array}{c}\text { Quadratic } \\
\text { Media }\end{array}$ & $F$ & $p$ \\
\hline \multirow{2}{*}{ AI } & Mathematics & 356.45 & 356.45 & 0.310 & 0.527 \\
\cline { 2 - 6 } & Comprehension & 11020.14 & 11020.14 & 10.478 & 0.001 \\
\hline \multirow{2}{*}{ AII } & Mathematics & 123.47 & 123.47 & 0.145 & 0.245 \\
\cline { 2 - 6 } & Comprehension & 3456.45 & 3456.45 & 320.15 & 0.002 \\
\hline \multirow{2}{*}{ AIII } & Mathematics & 856.14 & 856.14 & 0.526 & 0.008 \\
\cline { 2 - 6 } & Comprehension & 24512.79 & 24512.79 & 21489.03 & 0.147 \\
\hline \multirow{2}{*}{ AIV } & Mathematics & 754.14 & 754.14 & 0.501 & 0.007 \\
\cline { 2 - 6 } & Comprehension & 19248.75 & 19248.75 & 20489.44 & 0.130 \\
\hline
\end{tabular}

Note. AI: evaluation anxiety, AII: phobic anxiety, AIII: mathematical anxiety and AIV: virtual anxiety. $\mathrm{P}<0.05$

\section{Discussion}

Anxious states, although frequent and normal, are associated with a wide variety of long-lasting and disabling psychopathological disorders [7]. An adequate evaluation of anxiety is a necessary requirement for the evaluation, diagnosis and planning of treatments adjusted to the characteristics of each participant of the test, thus enhancing their effectiveness and efficiency.

The ISRA-B is a reliable and valid instrument to assess anxiety in the three response systems - cognitive, physiological and motor - in general, as well as in the four specific traits or situational areas of evaluation anxiety, phobic anxiety, anxiety math and virtual anxiety. According to Cano \& Miguel [30], anxiety levels can be standardised according to the centile scores of the responses (Table 8). 
Table 8

ISRA-B classification table of anxiety levels according to dependent variables

\begin{tabular}{|c|c|c|c|c|c|}
\hline Centile Scores & AI & AII & AIII & AIV & Classification \\
\hline $21-24$ & & & & & Extreme anxiety \\
\hline $16-20$ & & & 18.04 & 16.14 & Severe anxiety \\
\hline $11-15$ & 12.87 & & & & Marked anxiety \\
\hline $6-10$ & & 8.45 & & & Moderate anxiety \\
\hline $0-5$ & & & & & Absence of anxiety \\
\hline
\end{tabular}

After analysing the results and placing them in the tables of anxiety levels, it can be observed that the highest levels are found in cognitive comprehension with an $F=13.04$ followed by physiological comprehension with an $F=6.17$ (Table 6). Regarding the levels of the situational areas, comprehension is found in the dependent variable virtual anxiety with an $F=20489.44$. Then, understanding is found in the dependent variable mathematical anxiety with an $F=21489.03$. These results in relation to the centile scores of responses with average level 18.08 of mathematical anxiety and 16.14 of virtual anxiety, demonstrate the drastic changes and secondary effects that virtual activities with prolonged distancing provide due to COVID-19 in engineering students from the UNACH.

It can be explained that the levels of anxiety and concern about digital interconnectivity are strong, according to Leurs \& Smets [31] students must always have a constant communication framework, this allows a balance between education and friendship. On the other hand, statistically significant differences were detected in terms of understanding. The analysis of variance carried out indicated that there are differences in the cognitive response system. Demonstrating the need to improve virtual activities and have a better level of understanding in mathematical activities.

The lack of open, non-digital communication between students, for the exchange of ideas, opinions, homework, among others, generates a desire for communication. Faced with this situation, as Liu et al. [32], Aning and Baharum [33], Zulkardi et al. [34] early strategies are necessary for the prevention and treatment of the psychological effects that a pandemic such as COVID-19 can create. These results lead to the conclusion that, in the process of mathematical anxiety, the alternative explanation for these statistical behaviours is because the descriptors are related to each other in a limited way. Beliefs, attitudes, and emotions make up an inseparable triad, a harmonious whole in which it is not convenient to treat them as individual entities, since university students need your constant support to achieve surpassing future goals. 


\section{Conclusion}

Our work has led us to conclude that this research is not clinical but prospective. The exploration carried out, by no means infallible, aims to detect trends or clues that allow the extraction of basic psycho-pedagogical guidelines that guide the construction of healthy university environments at UNACH. Despite investigative prudence, one cannot help but show concern about the considerable number of students in the sample with severe anxiety on the ISRA-B scale according to Cano \& Miguel. In general, it is known that severe anxiety is related to individual, family, social and environmental factors. Among the individual factors that increase the risk of a university student having anxiety problems, the limited capacity to handle stressful events, the lack and restricted social skills due to COVID-19, should be highlighted.

In the family sphere, the dysfunctionality noticed in conflicts, violence, emotional ambivalence, lack of love, lack of cohesion, insecurity and anomic / negligent, authoritarian or overprotective parenting style, the presence of a family member with COVID-19 disease. During the COVID-19 pandemic, serious physical, economic and emotional problems are perceived, these associated conditions can increase states of anxiety. The greater the alteration of coexistence in the family, the more likely it is that the mental health of its members will deteriorate. Of course, the impact of the family climate on the development of an anxiety disorder depends on the young person's own personality, as well as the interpretation they make of what happened and their perceived ability to cope.

Among the social and environmental factors of Ecuadorian society, one must think of the general negative impact of economic and professional stress, often preceded by the university engineer. The situations of solitary confinement / isolation must also be considered, because of the transfer of residence of the young person or because of the difficulties of psychosocial adaptation at UNACH. Since 2020 March 14, many students have been isolated from their relatives and others from their friends, which increases the level of anxiety due to physical and emotional withdrawal.

In the technological aspect, there are inconveniences and problems of connectivity on the Internet. The lack of connection generates stress and mathematical anxiety in students. The concern of being badly evaluated if they do not attend classes with online activities. There is also concern about not delivering homework on time. At the assessment level, students create mathematical anxiety, to complete the activities on time. Many teachers do not consider the stress caused by virtual activities, affecting the academic and emotional performance of students.

Finally, among the limitations of this study, it can be noted that no sociodemographic questionnaire is used. The number of participants is moderate with only 120 students. In the sample, in addition, there is a disproportion 
between the number of women and men, explained by the existing asymmetry in the students who study the various engineering careers. Despite the limitations mentioned, the research carried out confirms the existence of severe anxiety in a significant part of the sample and may contribute to the promotion of anxiety preventive measures in the university setting of engineering students. In any case, it is advisable to carry out more research that does not suffer from the limitations and that, ultimately, favours the construction of healthy university environments that promote the teaching of mathematics in virtual mode.

\section{References}

1. Podkhodova N., Snegurova V., Stefanova N., Triapitsyna A., Pisareva S. Assessment of mathematics teachers' professional competence. Journal on Mathematics Education. 2020; 11 (3): 477-500.

2. Lara Barragán A. Internal Report University Center of Exact Sciences and Engineering of the University of Guadalajara. Guadalajara: Department of Physics. Guadalajara: Mexico; 2011.

3. Mendoza D., La Madriz J., López M., Ramón V. Research competencies of higher-education teaching staff based on emotional intelligence. Mediterranean Journal of Social Sciences. 2018; 9 (5): 41-52. DOI: 10.2478/mjss-2018-0137

4. Santibáñez Velilla J. Pygmalion effect of the teacher on the student's encouragement, in Communication and Pedagogy. New Technologies and Teaching Resources. 2001; 176: 17-24.

5. Viseu F., Martins P., Leite L. Prospective primary school teachers' activities when dealing with mathematics modelling tasks. Journal on Mathematics Education. 2020; 11 (2): 301-318. DOI: 10.22342/jme.11.2.7946.301-318

6. Ledoux J. The emotional brain, fear, and the amygdala. Cellular and Molecular Neurobiology. 2003; 23 (4): 727-738. DOI: 10.1023/A:1025048802629

7. Cano-Vindel A., Dongil-Collado E., Salguero J., Wood C. Cognitive behavioural intervention in anxiety disorders: An update. Psychological Information. 2011; 102: 4-27. (In Spanish)

8. Zivcic Becirevic I., Smojver Azic S., Martinac Dorcic T., Juretic J. Depression and anxiety in university students. Psychiatry. 2015; 18 (4): 32-33.

9. Graham C. Characteristics of individuals with fear of spiders. Anxiety Research. 1991; 4 (4): 299-314. DOI: 10.1080/08917779208248798

10. Addison N. The doll and pedagogic mediation: Teaching children to fear the 'other'. Sex Education. 2008; 8 (3): 263-276. DOI: 10.1080/14681810802218148

11. Islam F. Psychological distress and its association with socio-demographic factors in a rural district in Bangladesh: A cross-sectional study. PLoS ONE. 2019; 14 (3): e0212765. DOI: $10.1371 /$ journal.pone.0212765

12. Morris J., Firkins A., Millings A., Mohr Ch., Redford P., Rowe A. Internet-delivered cognitive behavior therapy for anxiety and insomnia in a higher education context. Anxiety, Stress, \& Coping. 2015; 29 (4): 415-4317. DOI: 10.1080/10615806.2015.1058924

13. Gould D., Krane V. The arousal-athletic performance relationship: Current status and future directions. In: T. Horn (ed.). Advances in sport psychology. Champaign: Human Kinetics; 1992. p. 119-141. 
14. Serrano C., Rojas A., Ruggero C. Depression, anxiety and academic performance in college students. Intercontinental Journal of Psychology and Education. 2013; 15 (1): 47-60.

15. Agudelo D. M., Casadiegos C. P., Sánchez D. L. Characteristics of anxiety and depression in college students. International Journal of Psychological Research. 2008; 1 (1): 34-39.

16. Pedrelli P., Nyer M., Yeung A., Zulauf C., Wilens T. College students: Mental health problems and treatment considerations. Academic Psychiatry: The Journal of the American Association of Directors of Psychiatric Residency Training and the Association for Academic Psychiatry. 2015; 39 (5): 503-511. DOI: 10.1007/s40596-014-0205-9

17. Palacios A., Hidalgo S., Maroto A., Ortega T. Causes and consequences of mathematics anxiety. A structural equation mode. Enseñanza de las Ciencias. 2013; 31 (2): 93-111. (In Spanish)

18. Hembree R. The nature, effects, and relief of mathematics anxiety. Journal for Research in Mathematics Education. 1990; 21 (1): 33-46.

19. Escalera-Chávez M., Moreno-García E., García-Santillán A., Córdova-Rangel A. Factors that promote the level of anxiety towards mathematics in upper middle-level students in the Rioverde San Luis Potosí region. European Journal of Education Studies. 2016; 2 (1): 8-22. DOI: 10.46827/ejes.v0iO.171 (In Spanish)

20. Smith S. Early childhood mathematics. Boston: Allyn \& Bacon; 1997. 278 p.

21. Seng E. The influence of the pre-university students' mathematics test anxiety and numerical anxiety on mathematical performance. International Education Studies. 2015; 8 (11): $162-168$

22. Devine A., Fawcett K., Szucs D., Dowker A. Gender differences in math sensitivity and relationship to mathematical performance while controlling exam anxiety. Behavioral and Brain Functions. 2012; 8 (1): 33-41.

23. Hernández R., Fernández C., Baptista M. Research methodology. Mexico: Mc Graw Hill; 2014. 600 p. (In Spanish)

24. Erba J., Ternes B., Bobkowski P., Logan T., Liu Y. Sampling methods and sample populations in quantitative mass communication research studies: A 15-year census of six journals. Communication Research Reports. 2018; 35 (1): 42-47. DOI: 10.1080/08824096.2017.1362632

25. Nguyen Hoang T., Duong Thi A., Mai Van L., Nguyen Minh N., Nguyen Thanh V. Formative assessment in the teacher education in Vietnam. Journal of Hunan University Natural Sciences [Internet]. 2020 [cited 2020 Aug 21]; 47 (8): 1-18. Available from: http://jonuns. com/index.php/journal/article/download/429/427

26. Zahran Al Kindy A., Mad Shah I., Jusoh A. Consideration and methodological approaches in studying transformational leadership impact on work performance behaviors. International Journal of Advanced Research. 2016; 4 (1): 889-907.

27. Tobal M., Cano A. Brief Anxiety Situations and Responses Inventory-ISRA. B. Experimental version. Madrid: TEA; 1994. 42 p. (In Spanish)

28. Tobal M., Cano A. Anxiety Situations and Response Inventory Manual - ISRA-B [M]. Madrid: TEA; 1986. 45 p. (In Spanish)

29. Mendoza D., Gomez S., Gomez J. The emotional intelligence for the improvement of the teaching competences in the facilitators of the Universidad Iberoamericana del Ecuador. Opción. 2018; 34 (18): 2018-2048. (In Spanish)

30. Cano A., Miguel J. Inventory of situations and responses of manual ISRA anxiety. Madrid: TEA Editions; 1997. 46 p. (In Spanish)

31. Leurs K., Smets K. Five questions for digital migration studies: Learning from digital connectivity and forced migration in(to) Europe. Social Media + Society. 2018; 1-16. DOI: $10.1177 / 2056305118764425$ 
32. Liu S., Yang L., Zhang C., Xiang Y., Liu Z., Hu S. Online mental health services in China during the COVID-19 outbreak. Lancet Psychiatry. 2020; 7 (e1): 7-8.

33. Aning A., Baharum A. E-learning design in Malaysian higher educational institutions: Principles and guidelines. Journal of Hunan University Natural Sciences [Internet]. 2020 [cited 2020 Aug 21]; 47 (10): 123-130. Available from: http://jonuns.com/index.php/ journal/article/download/455/453

34. Zulkardi Z., Meryansumayeka M., Putri R., Alwi Z., Nusantara D., Ambarita S., Maharani Y., Puspitasari L. How students work with pisa-like mathematical tasks using COVID-19 context. Journal on Mathematics Education. 2020; 11 (3): 405-416. DOI: 10.22342/ jme.11.3.12915.405-416

\section{Information about the authors:}

Derling Mendoza - Dr. Sci. (Education), Research Professor, Department of Mathematics, Faculty of Education, University UTE / Universidad UTE; Teacher of Mathematics, Department of Experimental Sciences, National University of Education (UNAE) / Universidad Nacional de Educación UNAE; ORCID https://orcid.org/0000-0001-8275-3687, Scopus ID 57205188813, Researcher ID N-1162-2018; Quito (Pichincha), Azogues (El Cañar), Ecuador. E-mail: derling.mendoza@ute.edu.ec

Magda Cejas - PhD (Economics and Business), Research Professor, Research and Administration Department, Faculty of Political and Administrative Sciences, National University of Chimborazo / Universidad Nacional de Chimborazo (UNACH); Teacher of Epistemology and Research, Department of Administration, Armed Forces University / Universidad de las Fuerzas Armadas (ESPE); ORCID https://orcid.org/0000-0002-0618-3608, Researcher ID G-8211-2019; Riobamba (Chimborazo), Latacunga (Cotopaxi), Ecuador. E-mail: magda.cejas@unach.edu.ec

Gabriela Rivas - M. Sci. (Educational Research), Computer Education Teacher, Software Development and Research Department, Metropolitan Institute of Technology (ITSQMET) / Instituto Tecnológico Superior Quito Metropolitano (ITSQMET); Teacher of Education and Technology, Faculty of Education, Libertador Experimental Pedagogical University / Universidad Pedagógica Experimental Libertador (UPEL); ORCID https://orcid.org/0000-0001-9766-318; Quito (Pichincha), Ecuador; Barquisimeto (Lara), Venezuela. E-mail: gabrielarivasu@gmail.com

Carmen Varguillas - PhD (Education), Professor of Curriculum Design, Teacher of Reading and Writing of Academic Texts, Department of Pedagogy of Experimental Mathematical and Physical Sciences, Faculty of Education, Humanities and Technologies, National University of Chimborazo / Universidad Nacional de Chimborazo (UNACH); ORCID https://orcid.org/00000002-3834-2474; Riobamba (Chimborazo), Ecuador. E-mail: cvarguillas@unach.edu.ec

Conflict of interest statement. The authors declare that there is no conflict of interest.

Received 12.11.2020; accepted for publication 13.01.2021.

The authors have read and approved the final manuscript.

\section{Информачия об авторах:}

Мендоса Дерминг - доктор педагогических наук, профессор-исследователь кафедры математики факультета образования Центрального университета (UTE); преподаватель 
математики кафедры экспериментальных наук Национального университета образования (UNAE); ORCID 0000-00018275-3687, Scopus ID 57205188813, Research ID N-1162-2018; Кито (Пичинча), Асогес (Каньяр), Эквадор. E-mail: derling.mendoza@ute.edu.ec

Cexac Магда - PhD (экономика и бизнес), профессор-исследователь кафедры исследований и управления факультета политических и административных наук Национального университета Чимборасо (UNACH); преподаватель эпистемологии и исследований кафедры управления Университета вооруженных сиц (ESPE); ORCID 0000-0002-0618-3608, Researcher ID G-8211-2019; Риобамба (Чимборасо), Аатакунга (Котопахи), Эквадор. E-mail: magda.cejas@unach.edu.ec

Ривас Габриэла - магистр (педагогические исследования), преподаватель информатики кафедры исследований и разработки программного обеспечения Городского технологического института (ITSQMET); преподаватель педагогики и технологии факультета образования Экспериментального педагогического университета Libertador (UPEL); ORCID

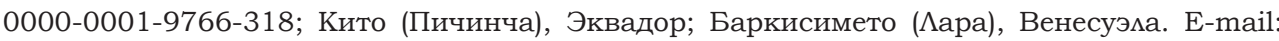
gabrielarivasu@gmail.com

Варгуимлас Кармен - PhD (педагогика), профессор разработки учебных программ, преподаватель чтения и написания академических текстов кафедры педагогики экспериментальных математических и физических наук факультета образования, гуманитарных наук и технологий Национального университета Чимборасо (UNACH); ORCID 0000-00023834-2474; Риобамба (Чимборасо), Эквадор. E-mail: cvarguillas@unach.edu.ec

Информация о конфликте интересов. Авторы заявмяют об отсутствии конфмикта интересов.

Статья поступила в редакцию 12.11.2020; принята в печать 13.01.2021.

Авторы прочитали и одобрили окончательный вариант рукописи. 